\title{
Preparation of strawberry Lassi
}

\author{
B.K. GHULE, R.J. DESALE, M.S. GAVHANE AND M.C. KHORE
}

\begin{abstract}
In present study of strawberry fortified Lassi the chemical compostion observed as fat content ranges from 3.25 to 3.11, protein from 3.64 to 3.78 , lactose from 3.73, to 3.82, total sugar 13.92 to 16.29 , ash from 0.73 to 0.8 . Acidity (\% LA) from 0.90 to 1.02 and $\mathrm{pH}$ from 4.13 per cent, respectively. The fat content of Lassi samples is decreases as increase in the level of strawberry pulp while lactose content is increases as increase in the level strawberry pulp. The overall acceptability for sensory score for Lassi prepared by using 5 per cent strawberry pulp is (8.09 to 7.90). The mean lactobacilli count was observed to be $4.33 \times 10^{7} \mathrm{cfu} /$ $\mathrm{ml}$ lit was observed that Lassi samples under study did not show presence of any yeast and mould growth. The cost for the sensorial superior combination Lassi prepared with 8 per cent sugar and 5 per cent strawberry pulp could make a $200 \mathrm{ml}$ serving at Rs. 6.80 which may be sufficiently lower with the value added and nutritionally enriched combination of strawberry pulp.
\end{abstract}

KEY WORDS : Dahi, Lassi, Strawberry pulp

How TO CITE THIS PAPER : Ghule, B.K., Desale, R.J., Gavhane, M.S. and Khore, M.C. (2015). Preparation of strawberry Lassi. Res. J. Animal Hus. \& Dairy Sci., 6(1) : 22-26.

\section{MEMBERS OF RESEARCH FORUM}

Address for correspondence :

B.K. Ghule, Department of Animal Husbandry and Dairy Science, Post Graudate Institute, Mahatma Phule Krishi Vidyapeeth, Rahuri, AHMEDNAGAR (M.S.) INDIA Email : balajighule111@gmail.com

Associated Authors':

R.J. Desale, M.S. Gavhane and M.C. Khore, Department of Animal Husbandry and Dairy Science, Post Graudate Institute, Mahatma Phule Krishi Vidyapeeth, Rahuri, AHMEDNAGAR (M.S.) INDIA 